OPEN ACCESS

Edited by:

Xuan Yu,

Sun Yat-sen University, China

Reviewed by:

Xudong Zhu,

Xiamen University, China

Rogger Correa,

Forestry Corporation of New South

Wales, Australia

*Correspondence:

Xiuzhen $\mathrm{Li}$

xzli@sklec.ecnu.edu.cn

Specialty section: This article was submitted to Marine Ecosystem Ecology, a section of the journal Frontiers in Marine Science

Received: 05 November 2021 Accepted: 23 December 2021

Published: 13 January 2022

Citation: Yuan Y, Li X, Xie Z, Xue L, Yang B, Zhao $W$ and Craft CB (2022) Annual Lateral Organic Carbon Exchange Between Salt Marsh and Adjacent

Water: A Case Study of East Headland Marshes at the Yangtze Estuary. Front. Mar. Sci. 8:809618. doi: 10.3389/fmars.2021.809618

\section{Annual Lateral Organic Carbon Exchange Between Salt Marsh and Adjacent Water: A Case Study of East Headland Marshes at the Yangtze Estuary}

\author{
Yiquan Yuan ${ }^{1,2}$, Xiuzhen Li ${ }^{1,3 *}$, Zuolun Xie ${ }^{1}$, Liming Xue ${ }^{1}$, Bin Yang ${ }^{1}$, Wenzhen Zhao ${ }^{1}$ and \\ Christopher B. Craft ${ }^{4}$
}

'State Key Laboratory of Estuarine and Coastal Research, Institute of Eco-Chongming, East China Normal University, Shanghai, China, ${ }^{2}$ Shanghai Wildlife and Protected Natural Areas Research Center, Shanghai, China, ${ }^{3}$ Yangtze Delta Estuarine Wetland Ecosystem Observation and Research Station, Ministry of Education \& Shanghai Science and Technology Committee, Shanghai, China, ${ }^{4}$ O'Neill School of Public and Environmental Affairs, Indiana University, Bloomington, IN, United States

Blue carbon $(\mathrm{C})$ ecosystems (mangroves, salt marshes, and seagrass beds) sequester high amounts of $\mathrm{C}$, which can be respired back into the atmosphere, buried for long periods, or exported to adjacent ecosystems by tides. The lateral exchange of $\mathrm{C}$ between a salt marsh and adjacent water is a key factor that determines whether a salt marsh is a C source (i.e., outwelling) or sink in an estuary. We measured salinity, particulate organic carbon (POC), and dissolved organic carbon (DOC) seasonally over eight tidal cycles in a tidal creek at the Chongming Dongtan wetland from July 2017 to April 2018 to determine whether the marsh was a source or sink for estuarine C. POC and DOC fluxes were significantly correlated in the four seasons driven by water fluxes, but the concentration of DOC and POC were positively correlated only in autumn and winter. DOC and POC concentrations were the highest in autumn $(3.54 \mathrm{mg} / \mathrm{L}$ and $4.19 \mathrm{mg} / \mathrm{L}$, respectively) and the lowest in winter and spring $(1.87 \mathrm{mg} / \mathrm{L}$ and $1.51 \mathrm{mg} / \mathrm{L}$, respectively). The tidal creek system in different seasons showed organic carbon (OC) export, and the organic carbon fluxes during tidal cycles ranged from -12.65 to $4.04 \mathrm{~g} \mathrm{C} / \mathrm{m}^{2}$. The intensity showed significant seasonal differences, with the highest in summer, the second in autumn, and the lowest in spring. In different seasons, organic carbon fluxes during spring tides were significantly higher than that during neap tides. Due to the tidal asymmetry of the Yangtze River estuary and the relatively young stage, the salt marshes in the study area acted as a strong lateral carbon source.

Keywords: blue carbon, salt marsh, organic carbon fluxes, tide, tidal creek

\section{INTRODUCTION}

Coastal salt marshes have a powerful carbon sink function, which is an important way to reduce atmospheric carbon dioxide $\left(\mathrm{CO}_{2}\right)$ and mitigate global climate change, due to the influence of tides (Bonan, 2008). Carbon sequestered in salt marshes, mangroves, seagrass beds and other ecosystems are called coastal "blue carbon," which belongs to the practice category of "nature-based solutions." While reducing greenhouse gas emissions, coastal wetlands can bring economic and social benefits to coastal countries (Mcleod et al., 2011; Lovelock and Duarte, 2019). 
The carbon sequestration function of coastal wetlands is mainly reflected in high primary productivity and carbon burial in sediments in the vertical direction. Wang et al. (2021a) estimated that the global carbon sequestration rate of salt marsh wetlands and mangroves was about $53.65 \mathrm{Tg} \mathrm{C} / \mathrm{yr}$. The carbon sequestration rate per unit area was 15 times that of terrestrial ecosystems, and about 50 times that of marine ecosystems (Wang et al., 2021b). This value is only the carbon burial rate in the vertical direction, but a large amount of carbon is also exported to the ocean through the exchange process of tidal action, which is rarely reported due to methodological constraints.

The export of carbon, in the form of dissolved inorganic carbon (DIC), dissolved organic carbon (DOC) and particulate organic carbon (POC), is known as outwelling and has been a subject of interest in several studies conducted in North America (Childers et al., 2000; Odum, 2002). Although DIC is identified as the important lateral carbon outwelling contributor (Santos et al., 2019), the organic fraction is more significant for processes in the estuaries, shelves and coastal zones. As an important labile carbon pool in water, DOC participates in complex biogeochemical cycles in the estuary, such as degradation and flocculation, and is finally buried in offshore marine sediments (Tipping et al., 1997). Coastal wetlands are generally considered to be a net source of offshore OC because most organic matter is exported by lateral tidal fluxes (Middelburg et al., 1997; Santos et al., 2004; Duarte et al., 2005; McKellar and Bratvold, 2006; Bauer et al., 2013). There have been many studies on OC fluxes, such as North Inlet Estuary (Dame et al., 1986) and North River Farms Marshes (Osburn et al., 2015) in Carolina, the Neponset Salt Marsh in Massachusetts (Schiebel, 2016), the Duplin River Marshes in Sapelo Island (Chalmers et al., 1985), Canary Creek Salt Marsh near Delaware Bay (Roman and Daiber, 1989) and Swartkops estuary in South Africa (Baird et al., 1987; Winter et al., 1996). The export rate of organic carbon varies from 158 to $745 \mathrm{~g} \mathrm{C} / \mathrm{m}^{2} \cdot \mathrm{yr}$, showing great variability. However, the outwelling phenomenon was still rarely studied in Asia (Howarth et al., 1996; Childers et al., 2000; Pinsonneault et al., 2017).

The tidal creek is an important pathway to produce horizontal organic carbon budget in coastal wetlands (Romigh et al., 2006; Bouillon et al., 2007). As one of the Ramsar Sites, the Chongming Dongtan Wetland is located at the northern part of the intersection of the Yangtze River and the East China Sea. It is densely covered with tidal creeks and is periodically submerged by rising tides, which provides an ideal place for studying the carbon budget of the salt marsh tidal creek system. Studies on carbon fluxes in the Chongming Dongtan wetland of the Yangtze Estuary indicate that lateral carbon transport is an important component of the carbon cycle. But this part of the carbon process is difficult to be identified by eddy covariance techniques and remote sensing estimation. To investigate the phenomenon, we conducted a series of studies on a small tidal creek system in the southern Chongming Dongtan wetland at the Yangtze Estuary. In the present study, we investigated seasonal DOC and POC concentrations and fluxes in a tidal creek at the Chongming Dongtan salt marsh. We hypothesized that the marsh served as a source of OC to the estuary. The objectives of the study were: (1) to characterize the seasonal concentrations and fluxes of DOC and POC and (2) to calculate annual fluxes between the marsh and estuary.

\section{MATERIALS AND METHODS}

\section{Study Area}

The Yangtze River is the third-longest river in the world, and its annual runoff and sediment discharge rank the fifth and fourth, respectively, in the world (Milliman and Farnsworth, 2011). The Yangtze River is also characterized by its high turbidity and fine grained sediment in the estuary of the great river basin in the world. The runoff and sediment discharge of the Yangtze River also have obvious seasonal variations. Generally, the runoff in the flood season (from May to October) can account for $71.7 \%$ of the whole year, while the sediment transport in the flood season can contribute $87 \%$, with monthly runoff and sediment transport in July the largest. The dry season is from November to the next April, with $28.3 \%$ of annual runoff and $13 \%$ of sediment discharge, respectively. The Yangtze Estuary is one of the typical braided-type estuaries, presenting a basic pattern of three-order bifurcations and four-outlet diversions into the sea. The Yangtze Estuary is a mesotidal estuary influenced by the interactions of runoff and tidal flow and also affected by waves and circulations of the continental shelf off the Yangtze River mouth.

The study area is near the North Channel of the Yangtze River estuary, dominated by ebbing flow (Figure 1). This region belongs to the subtropical monsoon climate zone, where southeast wind prevails in summer and northwest wind prevails in winter. The seasonal variation of rainfall is very obvious, with $41 \%$ of precipitation falling in summer. The hydrodynamic conditions of the study area are complex with irregularly semidiurnal tides. The tidal range in summer and autumn is higher than that in winter and spring. There are two obvious tidal processes every day and night, with two maximum and minimum tides each month. According to the Sheshan Gauging Station, the highest tide and average tide heights are $4.62 \mathrm{~m} \sim 5.95 \mathrm{~m}$ and $1.96 \mathrm{~m} \sim 3.08 \mathrm{~m}$, respectively. The average annual tidal range is $2.66 \mathrm{~m}, \sim 3.5 \mathrm{~m}$ during spring tides. The Highest Astronomical Tide (HAT) is $5.2 \mathrm{~m}$ above the Lowest Astronomical Tide (LAT), or $1 \mathrm{~m}$ higher than the Mean Spring High Tide (MSHT) (Yang et al., 2008).

The tidal creek selected for the present study is a shoal-flow current type. Runoff from the Yangtze River and tidal water continuously wash the flat surface, forming a high-density tidal creek system approximately $751 \mathrm{~m} / \mathrm{km}^{2}$ (Liu et al., 2012) in the eastern and southern tidal flats.

The most widely distributed vegetation in the Chongming Dongtan Wetland is Phragmites australis and Scirpus mariqueter, followed by Carex scabrifolia, Scirpus triqueter, Imperata cylindrica, and Juncus setchuensis, which occur as scattered patches (Huang et al., 2007; Ding et al., 2015). The supralittoral zone, which has an elevation of $2.5 \mathrm{~m}-3 \mathrm{~m}$ (Wusong elevation datum), is dominated by graminoid communities, while the intertidal zone has an elevation of $2-2.5 \mathrm{~m}$ and predominantly consists of sedge communities (Ge et al., 2015). The subtidal zone 

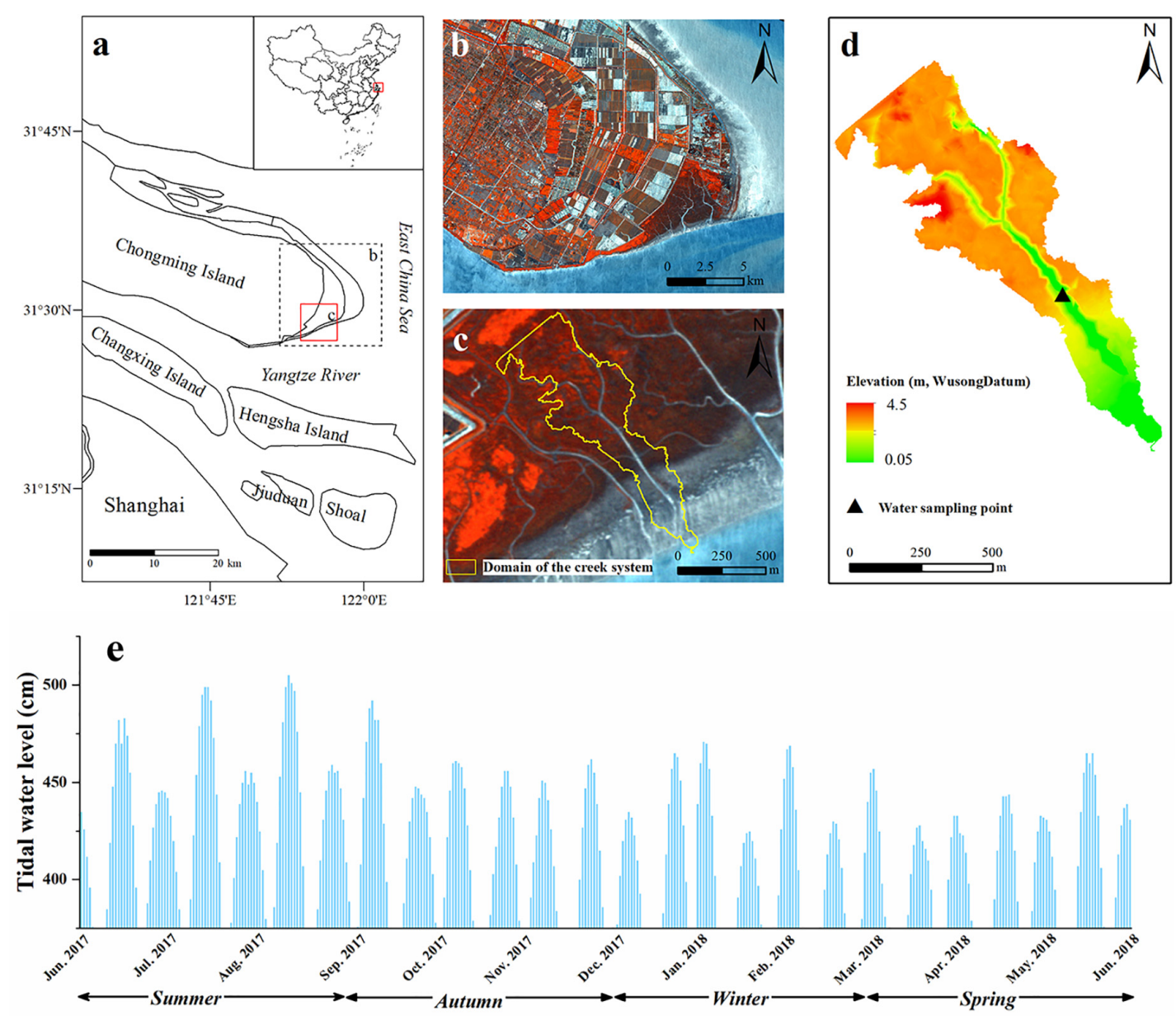

FIGURE 1 | Location of the study area and tidal oscillation [(a), Map of the Yangtze Estuary; (b), photo of the Chongming Dongtan marshes; (c), Boundary diagram of study area; (d), Elevation diagram of the study area; (e), tidal oscillation from June 1, 2017 to June 30, 2018].

has an elevation of less than $2.0 \mathrm{~m}$ and is a tidal flat with no vascular plants.

\section{Water Sampling and in-situ Data Collection}

We selected a typical tidal creek stretching from the northwest to southeast (Figure 1). From the summer of 2017 to the spring of 2018, water samples had been collected twice during the spring tides of each season, in July and October of 2017, and January and April of 2018, representing summer, autumn, winter, and spring, respectively. During the diurnal tide cycle, three $500 \mathrm{ml}$ water samples were collected at the same time every hour as duplicate samples for analysis of physical and chemical parameters. Water samples were collected in acid-washed HDPE bottles and kept in freezers in the field. Samples were kept in freezer until analysis, which was conducted within $2 \mathrm{~d}$ of sampling.

In-situ data, including water temperature and salinity (measured using SX836 Series Portable Electrochemical Meter, Sanxin Instrument Factory, Shanghai, China), and sampling site data (GPS-G350, UniStrong, China) were obtained.

\section{Dissolved Organic Carbon and Particulate Organic Carbon Concentration Measurements}

Water samples were filtered through pre-combusted $0.45 \mu \mathrm{m}$ nylon filters in-situ. Dissolved organic carbon samples obtained were stored in $20 \mathrm{~mL}$ glass screw bottles and kept in freezers. Dissolved organic carbon concentration was determined through high-temperature catalytic oxidation $\left(680^{\circ} \mathrm{C}\right)$ using a total organic carbon analyzer (TOC-VCPN; Shimadzu, Kyoto, Japan). The external standard working curve method was used to measure the DOC concentration. During the determination process, each sample was injected $3-5$ times in parallel, and the relative standard deviation was less than $2 \%$. During the determination, four samples were inserted as the standard sample (Florida Strait deep seawater, provided by Denins A. Hansell Laboratory of Miami University, with an average concentration of $44.7 \mu \mathrm{M}$ ) for data monitoring. When the concentration did not exceed the reference range, the next sample analysis and determination could be carried out. The instrument blank was $6 \sim 10 \mu \mathrm{M}$. 


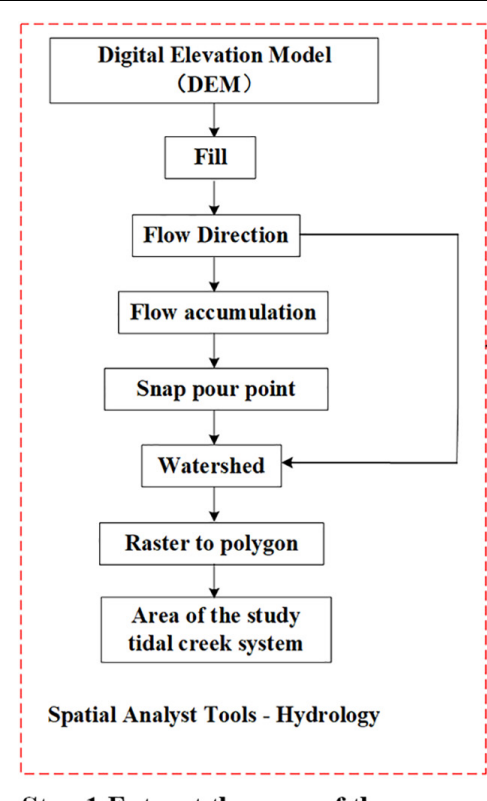

Step 1 Extract the area of the Study tidal creek system

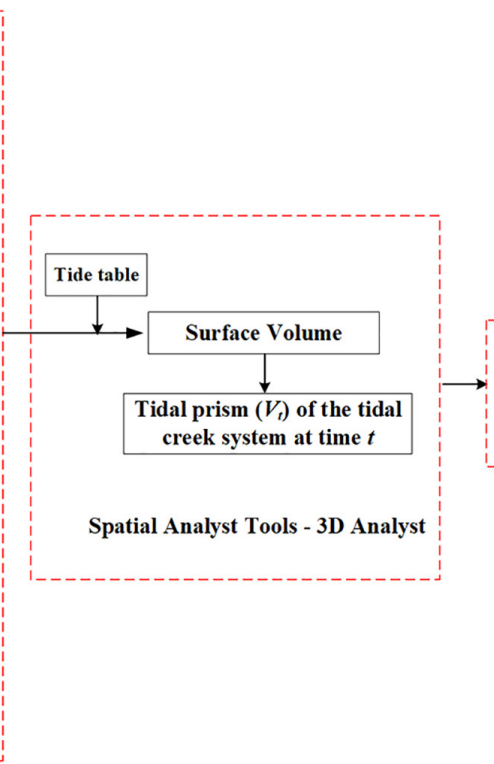

Step 2 Calculate the tidal prism

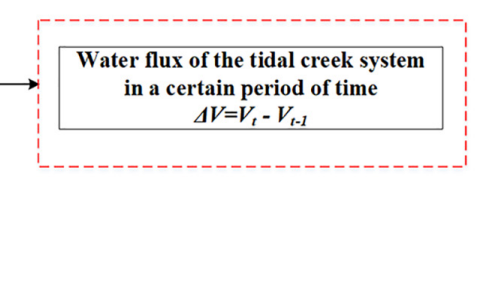

Step 3 Calculate water flux

FIGURE 2 | Water flux calculation diagram.

The determination of POC follows the method of elemental analyzer improved by Sharp (1974). Water samples for POC were kept in freezers before analyzation. Samples were filtered under low vacuum through a pre-weighed $0.7 \mu \mathrm{m}$ GF/F film previously dried at $450^{\circ} \mathrm{C}$ and subsequently dried to a constant weight in the laboratory. After acidification in a desiccator with concentrated hydrochloric acid vapor for approximately $12 \mathrm{~h}$, filter membranes were dried to a constant weight at $50^{\circ} \mathrm{C}$ in an oven. The samples were scraped off the glass fiber membranes and prepared for onboard measurement.

POC\% was measured using CHNOS Analyzer (Vario EL III; Elementar, Hanau, Germany). The external standard working curve was used as a quantitative method. The standard sample was potassium hydrogen phthalate (KHP, Japan Shimadzu Company). The measurement precision error was $<5 \%$.

\section{Data Analysis}

\section{Calculation of Water Fluxes}

According to the digital elevation model (DEM) obtained from the scanning and elevation measurement of the ground threedimensional laser scanner (Riegl VZ4000, Austria) in 2016, the elevation of the bare flat was $1.90 \pm 0.29 \mathrm{~m}$ ( $\mathrm{n}$ is the number of pixels, $n=9118$ ), the vegetation zone was $4.01 \pm 0.61 \mathrm{~m}$ $(n=85666)$, and the tidal creek was $2.19 \pm 0.33 \mathrm{~m}(n=8977)$. There was a $1 \mathrm{~h}$ time difference between the hourly tidal height data of the Sheshan station and the field observation data. Therefore, this study combined the actual situation of the sampling points and adopted the tidal height data of Sheshan station after 1-h delay. After the elevation was unified to the Wusong datum, the instantaneous flooding depth of each region is calculated as the difference between the instantaneous tidal heights derived from the tide table and the average tidal flat elevation.

During the low tide period, the tidal range was small and the tidal water cannot reach the sampling point. Therefore, data collected by Fei (2018) at a nearby site was used to represent the concentration of POC and DOC during the low tide period, so that the OC flux of the spring tides and the neap tides in four seasons can be calculated.

ArcGIS 10.2 (ESRI, Redlands, CA, United States) was used to calculate water fluxes (Figure 2). Watershed area and tidal prism were calculated using the Functional Surface module of ArcGIS 10.2. The elevation of the study area and tide table was standardized against the sea level (Wusong datum) before calculating the fluxes, and the hydrology module was used to extract area of the tidal creek system.

A tide table with real-time change was applied and elevation data provided by DEM was compared with the tidal height. The region was considered inundated when the tidal height was higher than the elevation of the salt marsh. To obtain the area of the study tidal creek system, a tidal prism in the region at time $t$ was obtained through pixel-by-pixel integration.

Based on the calculated tidal prism per hour, water flux $(\Delta V)$ was considered the difference between the two moments. When $\Delta V$ is $>0$, water flows into the study area, and vice versa.

$$
\text { Water flux }=\frac{\sum_{i=1}^{n}\left(h_{i, j+1}-h_{i, j}\right) \cdot d s}{t_{i, j+1}-t_{i, j}}
$$

where $i$ is the $i$ th pixel, the $n$ is the total number of pixels in the tidal creek system, $h_{i, j+1}$ and represent water depth of the $i$ th pixel at time $j+1$ and $j, d s$ is the size of each pixel. 


\section{Calculation of Organic Carbon Fluxes}

Tides in the region exhibit considerable diel asymmetry. Therefore, the net flux of water is not necessarily balanced throughout a complete flood and ebb tidal cycle (Dittmar, 1999). The calculation of daily net material fluxes thus necessitated the adjustment of the water fluxes to avoid methodological artifacts. For this purpose, salinity was used as a conservative parameter. Variations in salt fluxes between half-tidal cycles were compensated using an individual correction factor for each half-cycle $\left(x_{i}\right)$.

$$
x_{i}=\frac{1}{n} \sum_{i=1}^{n}\left(\sum_{t=t_{i b}}^{t_{i e}} s_{t} \cdot Q_{t}\right) / \sum_{t=t_{i b}}^{t_{i e}} s_{t} \cdot Q_{t}
$$

where $i$ is the number of sampling times, $x_{i}$ is correction factor, $t_{i b}$ is the beginning of a single sampling $i, t_{i e}$ is the end of a single sampling $i, s_{t}$ is the salinity at time $t_{k}$, and $Q_{t}$ is water flux, which is the difference in the tidal prism volume $\left(\mathrm{m}^{3}\right)$ per hour at time $t_{k}$.

Material flux increments were calculated as the product of water flux and material concentration during a lunar day (2 tidal cycles) to obtain net fluxes. The net fluxes throughout a lunar day were subsequently normalized to $24 \mathrm{~h}$ and to the tidal creek system area:

$$
\mathrm{F}=\sum_{i=1}^{n}\left(x_{i} \cdot \sum_{t=t_{i b}}^{t_{i e}} c_{t} \cdot Q_{t}\right) \cdot 24 h / T \cdot 1 / S
$$

where $\mathrm{F}$ is net material flux per day $(\mathrm{t}), c_{t}$ is material concentration at time $t_{k}(\mathrm{mg} / \mathrm{L}), T$ is sampling period $(\mathrm{h})$, and $S$ is the area of the tidal creek system (Dittmar and Lara, 2001).

Net fluxes of POC and DOC transported via tidal exchange were determined by multiplying each instantaneous volume estimation by the corresponding concentration. POC and DOC concentrations during neap tide were based on data collected by Fei et al. (2019) at a similar location to calculate C flux during neap tide, which facilitated the calculation of OC fluxes of the spring and neap tides per tidal cycle for four seasons. The OC fluxes of other unmeasured tidal cycles were obtained through linear interpolation after calculating OC fluxes of spring and neap tides, and the monthly OC fluxes were accumulated. The annual OC flux was obtained using a similar method.

\section{Statistical Analysis}

IBM SPSS Statistics 20.0 (IBM Corp., Armonk, NY, United States) was used to analyze data. Data were transformed before analyses to meet Kolmogorov-Smirnov and Levene's test requirements. One-way analysis of variance was used to compare variations in DOC and POC concentrations between flood and ebb tides. Pearson's correlation coefficient was used to determine the correlations among variables such as salinity, OC concentration, and OC flux. All tests of statistical significance were conducted at $p<0.05$.

\section{RESULTS}

\section{Seasonal Variation in Tidal Water Salinity}

The complex water mass of the Yangtze Estuary mainly comprises of Yangtze runoff, Yellow Sea Coastal Current, the Fujian and Zhejiang coastal currents, and the Taiwan current, which influence water salinity and turbidity (Su, 2001). The salinity difference between high tide period and low tide period is very small in the North Channel adjacent to the study area during a tidal cycle (Zhao et al., 2019). Salinity was inversely related to tide height (Figure 3). Affected by the Yangtze River diluted water, the salinity of the salt marsh water body was the lowest in summer $(0.05-0.80 \mathrm{ppt})$ and the highest in winter $(0.52-$ $4.42 \mathrm{ppt}$ ), which was consistent with the seasonal variation of Yangtze runoff. The stronger the runoff of the Yangtze River is, the shorter the upstream distance of salt water is, and the lower the salinity is.

\section{Seasonal Variations in Particulate Organic Carbon and Dissolved Organic Carbon Concentrations in the Tidal Creek}

The estimated mean annual POC concentration was approximately $2.8 \mathrm{mg} / \mathrm{L}$. POC concentrations varied among seasons, with high concentrations observed in October $(4.19 \pm 0.86 \mathrm{mg} / \mathrm{L})$ and low concentrations in April (1.51 $\pm 0.76 \mathrm{mg} / \mathrm{L})$ (Figure 4). Two patterns were observed: (1) in autumn and spring, the highest POC concentrations occurred at high tide and the lowest concentrations occurred at low tide; and (2) the inverse was observed in summer and winter, with low concentrations at high tide and relatively high concentrations at low tide (Figure 4).

The $\mathrm{C}$ contents of tidal waters that flush the tidal creek system were highly variable. Dissolved organic carbon concentrations were greater in summer $(2.98 \pm 0.79 \mathrm{mg} / \mathrm{L})$ and autumn $(3.54 \pm 0.78 \mathrm{mg} / \mathrm{L})$ than that in winter $(1.87 \pm 0.77 \mathrm{mg} / \mathrm{L})$ and spring $(1.98 \pm 0.41 \mathrm{mg} / \mathrm{L})$ (Figure 3). The maximum concentrations were observed when the tide levels were the lowest.

Particulate organic carbon (POC) and DOC concentrations were low during winter and spring relative to summer and autumn (Figure 4), which could be attributed to the plant senescence and low plant biomass during this period of the year. Water salinity in the study area was relatively low, and DOC and POC concentrations exhibited no distinct trends with variation in salinity (Figure 5), suggesting diversity in OC sources.

\section{Water Fluxes in the Tidal Creek System During Different Seasons}

Water flux is a key parameter in the calculation of material exchanges (Roman and Daiber, 1989). The tidal range of spring tide in summer was greater than that observed in other seasons due to the influence of astronomical tides. Therefore, the tidal prism and water fluxes were also significantly larger than those in other seasons. The average tidal prisms were $2.04 \times 10^{5} \mathrm{~m}^{3}$ (Jul. 

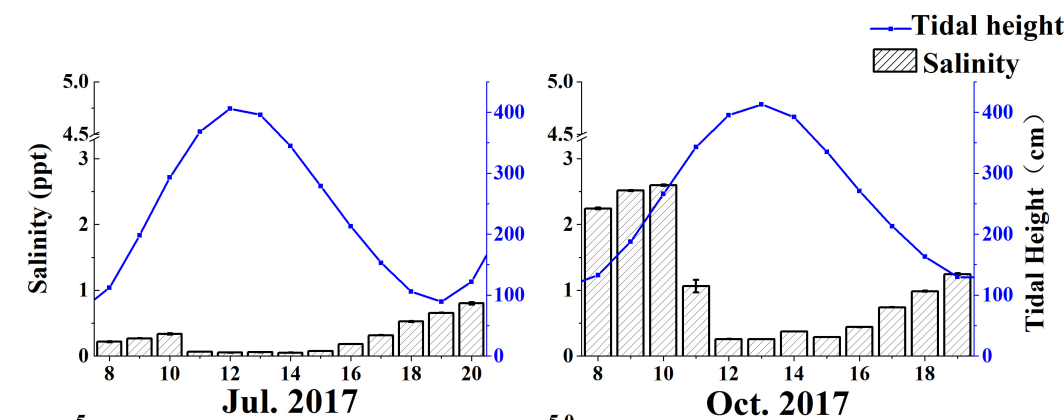

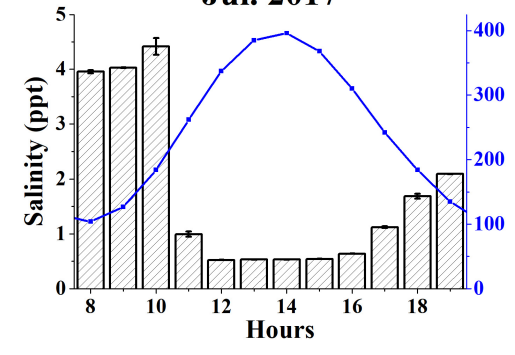

Jan. 2018

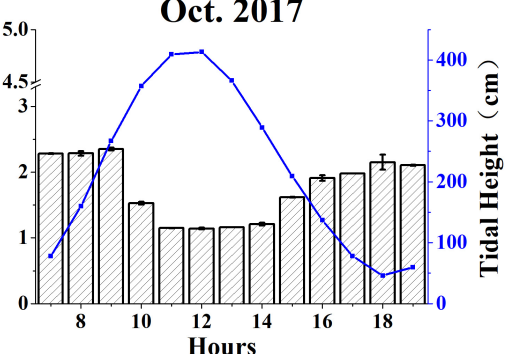

Apr. 2018

FIGURE 3 | Variations in water salinity as a function of tidal height in different seasons in southeast Chongming Dongtan wetland.

2017), $1.86 \times 10^{5} \mathrm{~m}^{3}$ (Oct. 2017), $1.52 \times 10^{5} \mathrm{~m}^{3}$ (Jan. 2018), and $1.46 \times 10^{5} \mathrm{~m}^{3}$ (Apr. 2018) respectively, in the tidal creek system during a spring tide (Figure 6).

Water flux during spring tide was approximately 2.5 fold of that during neap tide, except in October 2017. In addition to astronomical tides, water temperature and seasonal variations in sea level could also influence water fluxes within marsh-estuarine systems. During the spring tide, the water flows into the tidal creek system at the beginning of the flood tide, and the water flow out of the tidal creek system during the flood slack, and the water flows into the system during the summer ebb tide. During the neap tide, the direction of water flux except summer is basically consistent with that of tide fluctuation. The direction of water flux in summer is different from that in other seasons due to astronomical tides and circulation in the Yangtze Estuary (Zhu et al., 1997).

\section{Net Organic Carbon Fluxes in Different Seasons}

According to Fei (2018), DOC and POC concentrations were lower during neap tide than that during spring tide, which could be attributed to the removal of more materials by water during spring tide resulting from the input of organic matter that had been accumulated in the high, unflooded marsh areas between spring tide periods.

Net OC fluxes per tidal cycle are presented in Figure 7. The organic carbon fluxes during tidal cycles ranged from -12.65 to $4.04 \mathrm{~g} \mathrm{C} / \mathrm{m}^{2}$. The $\mathrm{C}$ export rate varied with seasons, with the highest export in summer and the lowest in spring. The export intensity of the neap tide was significantly lower than that of the spring tide due to less water movements.
Most of the OC in the salt marsh water occurred as DOC, which was exported over the four seasons during spring and neap tides except in July 2017, when import was observed during the neap tide (Figure 7). DOC flux was primarily driven by spring tide when much greater volumes of water were exchanged through the estuary.

\section{Correlation Analyses of Variables by Season}

Salinity was negatively correlated with tide height across all seasons (Table 1), demonstrating the significance of freshwater flow from flooding rivers during high tide. In summer, DOC concentrations in the Yangtze Estuary were positively correlated with salinity, at $1.86 \pm 0.61 \mathrm{mg} / \mathrm{L}$, suggesting that tidal dilution was a key factor influencing DOC over the period. In spring, POC concentration was negatively correlated with salinity; at $2.66 \pm 4.48 \mathrm{mg} / \mathrm{L}$, highlighting the contribution from marine sources.

The OC fluxes were strongly correlated with water fluxes (Table 1), and the relationships between C components (DOC and $P O C$ ) and water fluxes in the four seasons were significant. Therefore, water flux is the key parameter to be considered in the calculation of material exchange (Ivan et al., 1980). Net OC flux was primarily determined by water flux.

Dissolved organic carbon (DOC) and POC concentrations were significantly correlated only in autumn and winter, suggesting that POC and DOC could have been originated from a similar source, while other sources could have contributed to the OC in spring and summer. Furthermore, DOC concentrations could increase with the prolongation of the retention time of suspended POC (Zhang et al., 2005). Particulate organic carbon and DOC fluxes in each of the four seasons were 

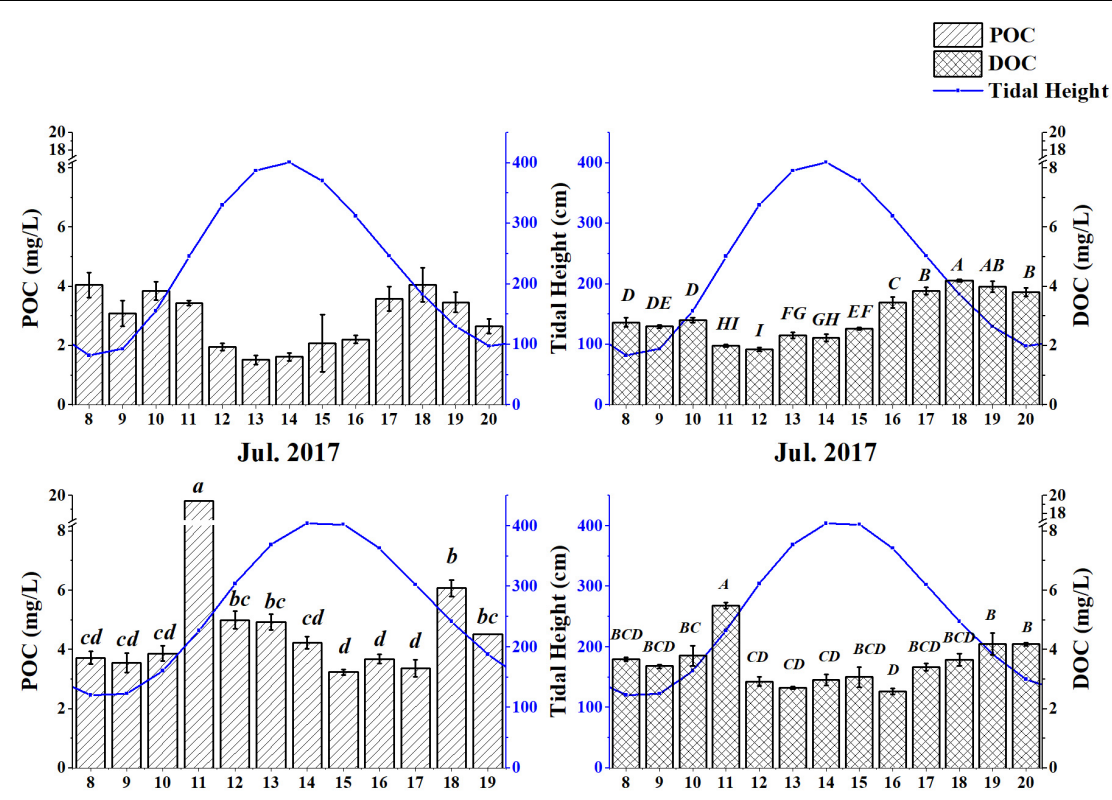

Oct. 2017

Oct. 2017

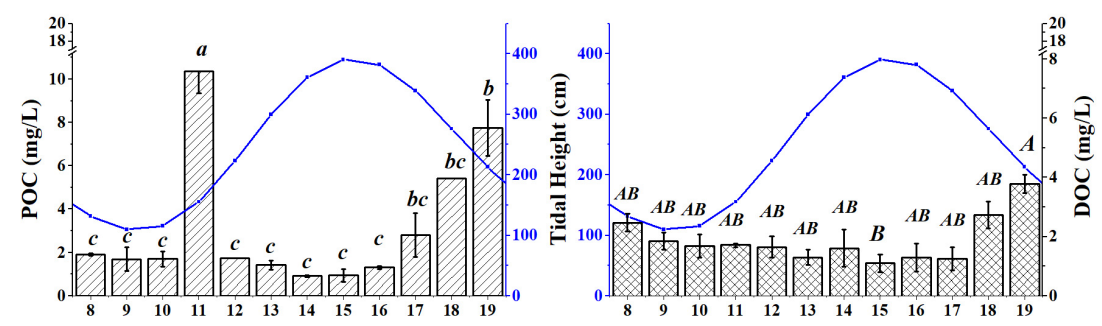

Jan. 2018

Jan. 2018

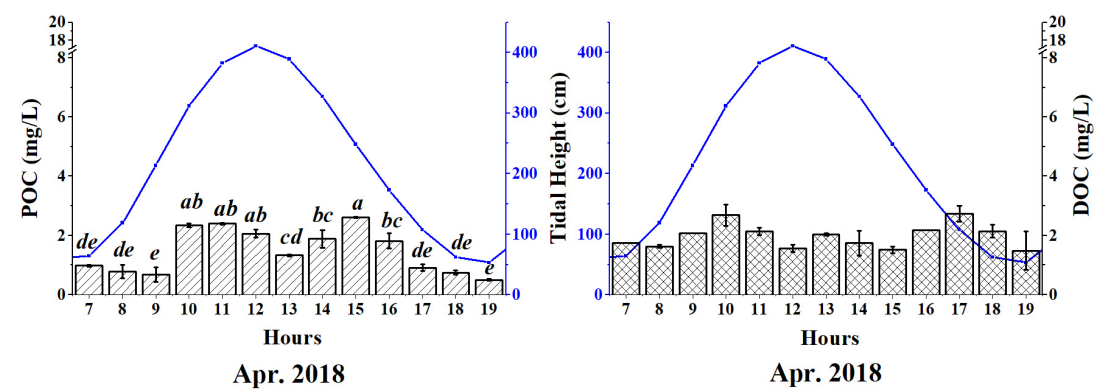

FIGURE 4 | Variations in POC and DOC concentrations during spring tides of different seasons in the tidal creek of Chongming Dongtan wetland.

positively correlated, demonstrating the relationships between the processes that produce, transform, and transport C. Metal ions in freshwater form hydroxides that co-precipitate with DOC to form organic particulate matter (Fry et al., 2015).

\section{DISCUSSION}

\section{Comparison of Yangtze Estuary to Typical Marsh-Estuary Systems Organic Carbon Concentrations}

As the world's third largest river estuary, the Yangtze Estuary receives high amounts of carbon, nitrogen, phosphorus and other elements transported by the strong runoff. The concentrations for DOC in the Yangtze Estuary ranged from 0.53 to $5.21 \mathrm{mg} / \mathrm{L}$, with an average of $1.86 \pm 0.61$, and for POC ranged from 0.16 to $34.8 \mathrm{mg} / \mathrm{L}$, with an average of $2.66 \pm 4.48$, respectively, in 2012 (Xing, 2014; Xing et al., 2014).

The estimated mean annual POC concentration at our study area was approximately $2.8 \mathrm{mg} / \mathrm{L}$, which was significantly higher than that $(0.68 \mathrm{mg} / \mathrm{L})$ reported by Bittar et al. (2016) at Skidaway River Estuary. However, POC concentration was within the same range as the concentration $(0.4-11.4 \mathrm{mg} / \mathrm{L})$ reported by Roman and Daiber (1989), and the concentration $(2.23-10.00 \mathrm{mg} / \mathrm{L})$ reported by Shisler and Jobbins (1977) (Table 2). In the summer of 2017, POC concentration in half tidal cycles ranged from 


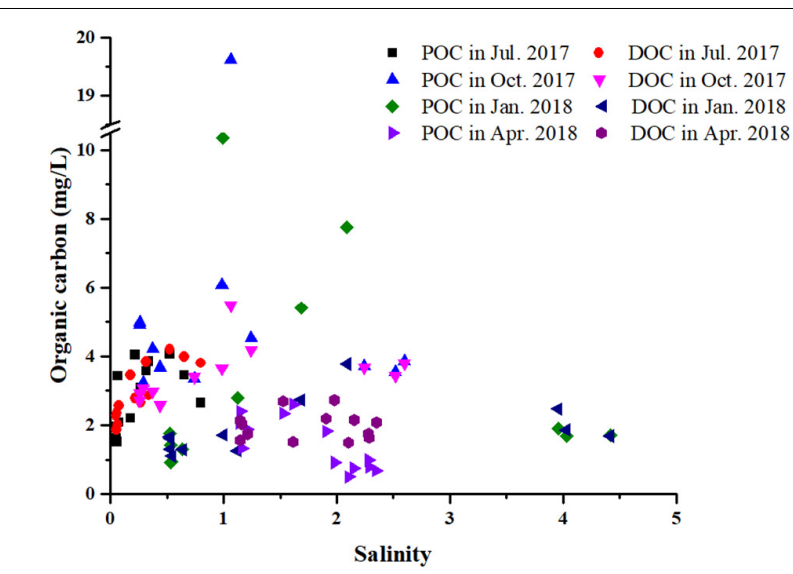

FIGURE 5 | Relationship between salinity and organic carbon in the tidal creek of Chongming Dongtan wetland.

$1.5 \mathrm{mg} / \mathrm{L}$ (at the highest tide level) to $4.05 \mathrm{mg} / \mathrm{L}$ (at the lowest tide level), which was consistent with the trend of greater flow velocity at high tide (Li et al., 2016). The observations are consistent with the results of Boon (1975), which revealed that particulate matter was exported when maximum flood and ebb tidal velocities were near high-slack water.
The impact of diluted Yangtze River water on POC concentration, especially in summer and autumn, cannot be overlooked. Runoff from the Yangtze River also carries high amounts of dissolved matter and suspended sediments, which constantly transport nutrients to waters near the estuary. Data from the Datong Hydrographic Gauging Station reveal that the average runoff during the dry season (November to April) is 40\% of the average in the flood season (May to October). Average POC concentrations during the dry season were $0.8 \pm 0.3 \mathrm{mg} / \mathrm{L}$, while the average concentration during the flood season was $1.1 \pm 0.4 \mathrm{mg} / \mathrm{L}$ (Liu et al., 2019). Similarly, temperature in summer and autumn is more favorable for phytoplankton growth. Therefore, the contribution of phytoplankton biomass to POC is greater in summer and autumn than that in winter. Particulate organic carbon could be largely originated from marine plankton, which is stimulated by low salinity. Furthermore, Duarte et al. (2013) observed that plant senescence in autumn could lead to increased POC export.

Dissolved organic carbon (DOC) generally decreased conservatively as salinity increased, suggesting that seawater dilution is a key factor influencing DOC concentrations (Figures 3, 4). DOC concentrations were significantly correlated with tidal height except in autumn and spring (Figure 4 and Table 2).

Organic carbon (OC) concentrations exhibited high variability due to variations in salinity, vegetation, and geomorphologic

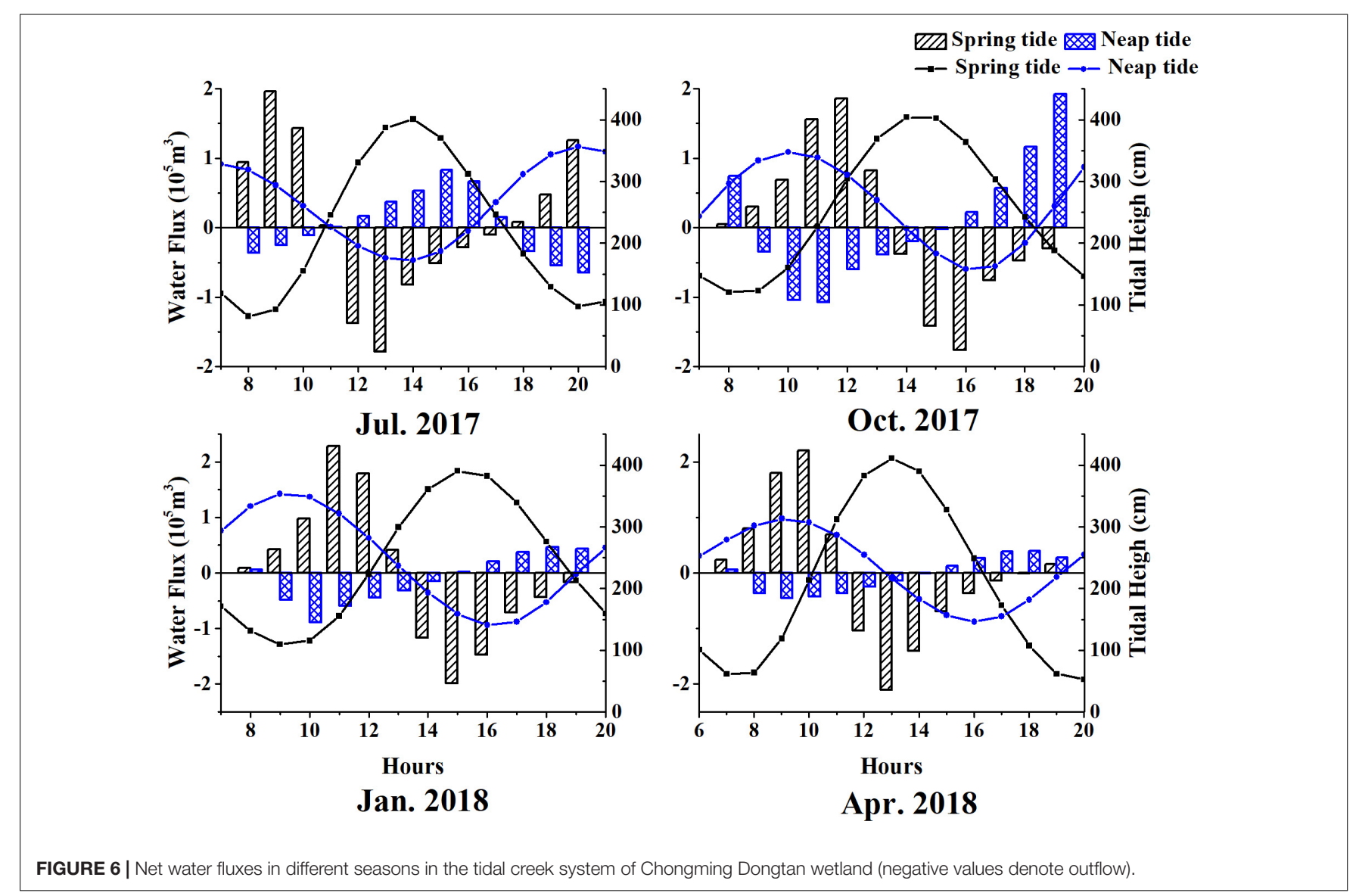


features. Our observed OC concentrations were within the range of values obtained by Van Damme et al. (2009). Particulate organic carbon and DOC concentrations obtained in the present study were consistent with those of other studies on POC and DOC concentrations in freshwater and brackish marshes (see Table 2). Dissolved organic carbon concentrations in the present study ranged from 1.1 to $5.5 \mathrm{mg} / \mathrm{L}$, with a mean annual concentration of $2.72 \mathrm{mg} / \mathrm{L}$, which are slightly lower than those presented in Table 2. However, DOC concentrations in the current study were similar to the concentrations in subtropical freshwater and brackish estuaries in the Pearl River, southern China, which were regulated by point source discharge and exhibited a high degree of anthropogenic influence. Taking into account the impact of vegetation on the Pearl River Estuary, the mangrove community can promote OC fixation and deposition of terrestrial organic matter through special complex aerial roots and brace root structures that capture suspended substances in water (Guo et al., 2016). Dissolved organic carbon concentrations were slightly higher than the concentrations in the Yellow River Delta marshes in northern China (Hu et al., 2012). Notably, the observed DOC concentrations were significantly lower than the concentrations in brackish marshes in the Coon Creek and Tampa Bay Estuaries in the United States (Table 2). By contrast, Tampa Bay marshes were considered as a source of DOC, leached from carbon-rich marshes and mangrove peats.

The concentration of POC is slightly higher than that of salt marshes and mangrove wetlands in the Pearl River Estuary. Considering the influence of vegetation, mangrove clusters have complex aerial roots, which can not only promote the fixation or deposition of terrestrial OC, but also support root structure and capture suspended matter in water (Guo et al., 2016). The average concentration during ebb was significantly lower than that during flooding (Figure 4), indicating that halophytes captured particulate matter during tidal flooding (Boon, 1975).

\section{Organic Carbon Fluxes}

Estuaries exhibit a high spatial and temporal variability in $\mathrm{C}$ concentrations (Wolaver and Marozas, 1986). If salt marsh and estuarine systems are considered as a whole, the export of DOC and POC remains consistent despite the different export intensities reported in previous studies, except for Flax Pond marshes. Flax Pond marshes should exhibit high OC export, although OC import was observed in the marshes (Woodwell et al., 1977). It is presumed that anthropogenic geomorphology significantly altered the normal transportation of materials into and out of the marsh.

Net OC fluxes in different seasons during tidal cycles suggest that the Chongming Dongtan salt marsh is a source of OC in the horizontal direction (Figure 7). Figure 7 illustrated the import and export processes of $\mathrm{OC}$ as typical tidal processes during the four seasons. The export process predominantly occurs during spring tide and supports a conclusion by Cao et al. (2013) that organic matter in a salt marsh is more likely to be transported to adjacent waters during the spring tide. A study by Childers (1994) revealed that organic matter fluxes were positively correlated with tidal height because of the large volume of water inundating the marsh, which could explain the large OC fluxes observed in

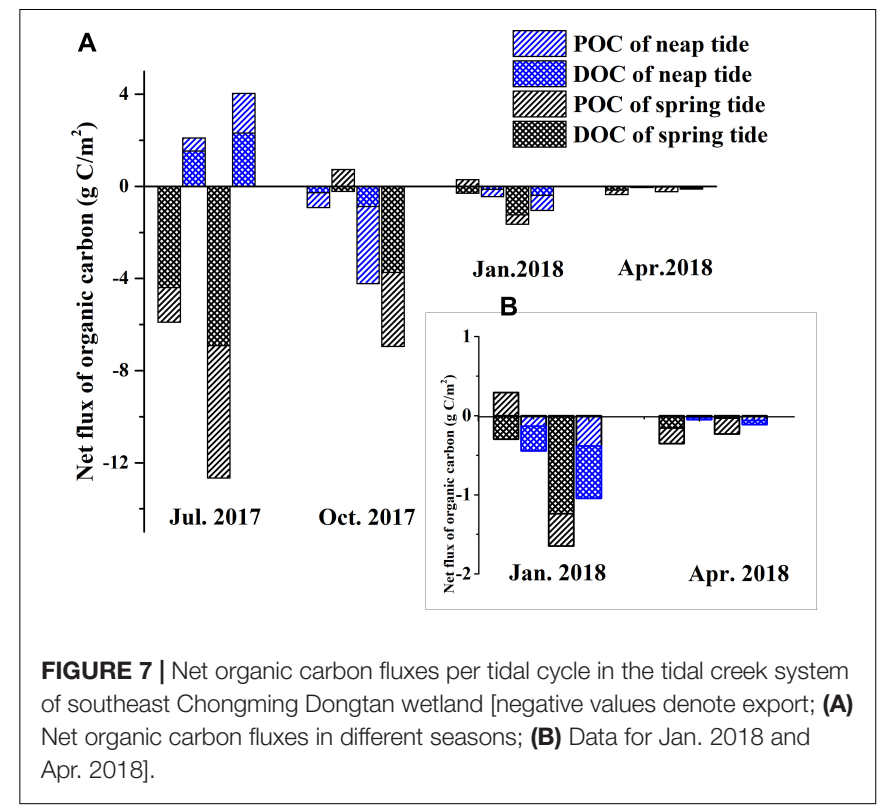

the present study. Moreover, there is an asymmetry between the fluctuation tides in the Yangtze Estuary. The ebbing duration is about $1 \mathrm{~h}$ longer than flooding duration, that is, the export time is longer than the import time. The study of Zhao et al. (2019) also showed that in addition to the longer ebbing duration, the flow velocity was also significantly larger than that of flooding tides. It was inferred that the asymmetry of tides strengthens the output of OC.

Figure 7 showed that the export of DOC is greater than that of POC, which is consistent with the findings of Odum (2002). The "outwelling hypothesis" postulates that salt marshes often transport organic matter and nutrients, primarily DOC, to the offshore waters (Odum, 2002). Maher et al. (2017) considered that the exported carbon generally came from the upper $\sim 40 \mathrm{~cm}$ of sediments. Pore water exchange can transfer buried carbon from salt marsh sediments to water and transport it to coastal waters (Charette, 2007; Santos et al., 2019; Webb et al., 2019). Dissolved organic carbon derived by pore water is the main way of OC export (Cai et al., 2003; Moore et al., 2006; Porubsky et al., 2014). OC from plant debris and rhizosphere is exchanged in tidal water in a dissolved form (Cifuentes, 1991; Drexler et al., 2020) and Moran et al. (1999) estimated that approximately $70 \%$ of the DOC in creeks was vascular plant-derived.

In addition to primary productivity, tidal mechanisms and topography of intertidal salt marshes are key factors influencing DOC output (Odum, 2002). Tidal range accounted for 33\% of the DOC flux variability (Childers, 1994). The Yangtze Estuary is a mesotidal estuary with annual average tidal range of $2.66 \mathrm{~m}$, which is larger than the range in most of the studies. The marsh in our study area was last reclaimed in 2001 (Yun, 2004), which is relatively young. Childers (1994) observed that young marshes exhibited a higher flux against tidal range relationship than old marshes. Therefore, OC fluxes in our study area are relatively high and are expected to decrease over time. The carbon burial rate in the intertidal zone of Chongming Dongtan salt marsh is 
TABLE 1 | Correlation analyses of variables by season.

\begin{tabular}{|c|c|c|c|c|c|c|c|c|c|c|c|c|c|c|c|c|}
\hline Season & Tide height (cm) & & Salinity & $\begin{array}{l}\mathrm{DOC} \\
(\mathrm{mg} / \mathrm{L})\end{array}$ & $\begin{array}{l}\text { POC } \\
\text { (mg/L) }\end{array}$ & $\begin{array}{l}\text { Water } \\
\text { flux } \\
\left(\mathrm{m}^{3}\right)\end{array}$ & $\begin{array}{c}\text { DOC } \\
\text { Flux (g } \\
\text { C/m².yr) }\end{array}$ & $\begin{array}{c}\text { POC } \\
\text { Flux (g } \\
\text { C/m² } \cdot \text { yr) }\end{array}$ & Season & Tide height (cm) & Salinity & $\begin{array}{l}\mathrm{DOC} \\
\text { (mg/L) }\end{array}$ & $\begin{array}{l}\text { POC } \\
\text { (mg/L) }\end{array}$ & $\begin{array}{l}\text { Water } \\
\text { flux } \\
\left(\mathrm{m}^{3}\right)\end{array}$ & $\begin{array}{c}\text { DOC } \\
\text { Flux (g } \\
\left.\mathrm{C} / \mathrm{m}^{2} \cdot \mathrm{yr}\right)\end{array}$ & $\begin{array}{c}\text { POC } \\
\text { Flux (g } \\
\left.\mathrm{C} / \mathrm{m}^{2} \cdot \mathrm{yr}\right)\end{array}$ \\
\hline \multirow[t]{7}{*}{ Summer } & Tide height (cm) & 1 & $-0.78^{\star \star}$ & $-0.87^{\star \star}$ & $-0.63^{*}$ & $-0.61^{*}$ & -0.51 & -0.32 & Autumn & $\begin{array}{l}\text { Tide height } \\
\text { (cm) }\end{array}$ & $-0.62^{*}$ & -0.29 & 0.23 & 0.34 & 0.30 & 0.41 \\
\hline & Salinity & & 1 & $0.83^{\star \star}$ & 0.48 & $0.58^{\star}$ & 0.49 & 0.29 & & Salinity & 1 & 0.39 & -0.25 & 0.19 & 0.11 & -0.02 \\
\hline & DOC (mg/L) & & & 1 & 0.48 & 0.36 & 0.32 & 0.14 & & $\begin{array}{l}\mathrm{DOC} \\
(\mathrm{mg} / \mathrm{L})\end{array}$ & & 1 & $0.79^{\star \star}$ & 0.39 & 0.13 & 0.27 \\
\hline & POC (mg/L) & & & & 1 & $0.68^{*}$ & $0.86^{\star *}$ & $0.75^{\star \star}$ & & POC (mg/L) & & & 1 & 0.39 & 0.38 & 0.36 \\
\hline & Water fluxes $\left(\mathrm{m}^{3}\right)$ & & & & & 1 & $0.77^{\star *}$ & $0.64^{*}$ & & Water fluxes $\left(\mathrm{m}^{3}\right)$ & & & & 1 & $0.88^{* \star}$ & $0.89^{* \star}$ \\
\hline & $\begin{array}{l}\text { DOC Flux (g } \\
\text { C/m².yr) }\end{array}$ & & & & & & 1 & $0.96^{\star \star}$ & & $\begin{array}{l}\text { DOC Flux } \\
\left(\mathrm{g} \mathrm{C} / \mathrm{m}^{2} \cdot \mathrm{yr}\right)\end{array}$ & & & & & 1 & $0.96^{\star \star}$ \\
\hline & $\begin{array}{l}\text { POC Flux (g } \\
\text { C/m².yr) }\end{array}$ & & & & & & & 1 & & $\begin{array}{l}\text { POC Flux } \\
\text { (g C/m².yr) }\end{array}$ & & & & & & 1 \\
\hline \multirow[t]{7}{*}{ Winter } & $\begin{array}{l}\text { Tide Height } \\
(\mathrm{cm})\end{array}$ & 1 & $-0.72^{\star \star}$ & $-0.70^{\star \star}$ & $-0.61^{*}$ & 0.01 & 0.20 & 0.36 & Spring & $\begin{array}{l}\text { Tide Height } \\
\text { (cm) }\end{array}$ & $-0.81^{\star \star}$ & 0.04 & $0.66^{*}$ & -0.07 & 0.11 & 0.05 \\
\hline & Salinity & & 1 & 0.36 & 0.10 & 0.25 & 0.12 & -0.08 & & Salinity & 1 & 0.01 & $-0.75^{\star \star}$ & 0.49 & 0.26 & 0.223 \\
\hline & DOC (mg/L) & & & 1 & $0.88^{\star \star}$ & 0.12 & -0.16 & -0.27 & & $\begin{array}{l}\mathrm{DOC} \\
(\mathrm{mg} / \mathrm{L})\end{array}$ & & 1 & 0.04 & 0.38 & 0.10 & 0.39 \\
\hline & POC (mg/L) & & & & 1 & 0.06 & -0.24 & -0.56 & & POC (mg/L) & & & 1 & -0.13 & 0.01 & -0.08 \\
\hline & Water fluxes $\left(\mathrm{m}^{3}\right)$ & & & & & 1 & $0.84^{\star *}$ & $0.80^{\star \star}$ & & Water fluxes $\left(\mathrm{m}^{3}\right)$ & & & & 1 & $0.85^{\star \star}$ & $0.80^{\star \star}$ \\
\hline & $\begin{array}{l}\text { DOC Flux (g } \\
\text { C/m².yr) }\end{array}$ & & & & & & 1 & $0.75^{\star \star}$ & & $\begin{array}{l}\text { DOC Flux } \\
\left(\mathrm{g} \mathrm{C} / \mathrm{m}^{2} \cdot \mathrm{yr}\right)\end{array}$ & & & & & 1 & $0.92^{\star \star}$ \\
\hline & $\begin{array}{l}\text { POC Flux (g } \\
\text { C/m².yr) }\end{array}$ & & & & & & & 1 & & $\begin{array}{l}\text { POC Flux } \\
\left(\mathrm{g} \mathrm{C} / \mathrm{m}^{2} \cdot \mathrm{yr}\right)\end{array}$ & & & & & & 1 \\
\hline
\end{tabular}

${ }^{*}$ Correlation is significant at the 0.05 level; ${ }^{* *}$ Correlation is significant at the 0.01 level. 
TABLE 2 | Comparison of particulate and dissolved organic carbon concentrations between southeast Chongming Dongtan salt marsh and marshes in other regions.

\begin{tabular}{|c|c|c|c|c|c|c|}
\hline \multirow[t]{2}{*}{ Site } & \multicolumn{2}{|c|}{ Concentration (mg/L) } & \multirow[t]{2}{*}{ Vegetation } & \multirow[t]{2}{*}{ Salinity } & \multirow{2}{*}{$\begin{array}{l}\text { Geomorphic } \\
\text { characters }\end{array}$} & \multirow[t]{2}{*}{ References } \\
\hline & POC & DOC & & & & \\
\hline $\begin{array}{l}\text { Southeast Chongming Dongtan, } \\
\text { Shanghai, China }\end{array}$ & $2.72 \pm 1.57$ & $2.61 \pm 0.98$ & $\begin{array}{l}\text { Phragmites australis, Scirpus } \\
\text { mariqueter and Scirpus triqueter }\end{array}$ & $0.05 \sim 4.41$ & Estuary & This study \\
\hline The Pearl River estuary, China & $1.2 \sim 2.7$ & $1.9 \sim 3.6$ & $\begin{array}{l}\text { Spartina alterniflora, Cyperus } \\
\text { malaccensis, and mangroves }\end{array}$ & $<1 \sim 5$ & Estuary & $\begin{array}{l}\text { Guo et al., } \\
2016\end{array}$ \\
\hline The Scheldt estuary, Belgium & $1.7 \sim 10.0$ & $0.4 \sim 7.1$ & $\begin{array}{c}\text { Salix sp., Phragmites australis, and } \\
\text { tall herb vegetation }\end{array}$ & $0.5 \sim 5$ & Estuary & $\begin{array}{l}\text { Van Damme } \\
\text { et al., } 2009\end{array}$ \\
\hline $\begin{array}{l}\text { Salt marshes of the Duplin River, } \\
\text { United States }\end{array}$ & $3.6 \sim 9.8$ & $3.1 \sim 11.1$ & Spartina alterniflora & & Embayment & $\begin{array}{c}\text { Chalmers et al., } \\
1985\end{array}$ \\
\hline $\begin{array}{l}\text { Tuckerton salt marsh, New Jersey, } \\
\text { United States }\end{array}$ & $2.23 \sim 10.00$ & $2.46 \sim 9.68$ & $\begin{array}{c}\text { Spartina patens and Spartina } \\
\text { alterniflora }\end{array}$ & & Tidal creek & $\begin{array}{l}\text { Shisler and } \\
\text { Jobbins, } 1977\end{array}$ \\
\hline $\begin{array}{l}\text { Coon Creek Marsh, Texas Coast, } \\
\text { United States }\end{array}$ & 3.35 (Mean) & 21.41 (Mean) & $\begin{array}{c}\text { Spartina patens, Distichlis spicata. } \\
\text { Scirpus olneyi, Spartinamaritimus, } \\
\text { Juncus roemerianus and Spartina } \\
\text { alterniflora }\end{array}$ & Brackish & Estuary & $\begin{array}{l}\text { Borey et al., } \\
1983\end{array}$ \\
\hline $\begin{array}{l}\text { the Neponset Salt Marsh, Boston, } \\
\text { Massachusetts, United States }\end{array}$ & & $3.6 \sim 7.2$ & $\begin{array}{c}\text { Spartina alterniflora, Spartina } \\
\text { patens and Phragmites australis }\end{array}$ & $5 \sim 10$ & Estuary & Schiebel, 2016 \\
\hline $\begin{array}{l}\text { Kirpatrick Marsh, sub-estuary of } \\
\text { Mid-Chesapeake Bay, } \\
\text { United States }\end{array}$ & & $3.03 \sim 7.84$ & $\begin{array}{c}\text { Spartina patens, Distichlis spicata. } \\
\text { Scirpus olneyi and Typha } \\
\text { augustifolia }\end{array}$ & $0 \sim 18$ & Sub-estuary & $\begin{array}{l}\text { Mitchell et al., } \\
2012\end{array}$ \\
\hline $\begin{array}{l}\text { Tampa Bay Estuary, Florida, } \\
\text { United States }\end{array}$ & & $\begin{array}{l}0.9 \sim 32.35 \\
\text { (Wet season) } \\
0.85 \sim 21.94 \\
\text { (Dry season) }\end{array}$ & Mangroves and salt marsh & $\begin{array}{l}\sim 2 \text { (Wet } \\
\text { season) }\end{array}$ & Estuary & $\begin{array}{l}\text { Moyer et al., } \\
2015\end{array}$ \\
\hline $\begin{array}{l}\text { The Bly Creek system, South } \\
\text { Carolina, United States }\end{array}$ & $0.63 \sim 5.3$ & $2.5 \sim 11.8$ & $\begin{array}{c}\text { Spartina alterniflora, Crassostrea } \\
\text { virginica }\end{array}$ & $15 \sim 35$ & Estuary & Dame, 1991 \\
\hline $\begin{array}{l}\text { Brackish and freshwater tidal } \\
\text { marshes along the shores of the } \\
\text { Chesapeake Bay, United States }\end{array}$ & & $2.8 \sim 10$ & $\begin{array}{c}\text { Typha angustifolia, Spartina patens, } \\
\text { Spartina cynosuroides, Distichlis } \\
\text { spicata, Iva frutescens and } \\
\text { Schoenoplectus americanus } \\
\text { (formerly Scirpus olneyi) and } \\
\text { cropland }\end{array}$ & $0.2 \sim 8.4$ & Estuary & $\begin{array}{l}\text { Tzortziou et al., } \\
2011\end{array}$ \\
\hline $\begin{array}{l}\text { Skidaway River Estuary Savannah, } \\
\text { United States }\end{array}$ & $0.11 \sim 0.68$ & $0.66 \sim 3.98$ & Spartina-dominated & $32 \pm 1.2$ & Estuary & $\begin{array}{l}\text { Bittar et al., } \\
2016\end{array}$ \\
\hline $\begin{array}{l}\text { The Canary Creek salt marsh, } \\
\text { United States }\end{array}$ & $0.4 \sim 11.4$ & $1.5 \sim 15.5$ & Spartina alterniflora & $22 \sim 30$ & Embayment & $\begin{array}{c}\text { Roman and } \\
\text { Daiber, } 1989\end{array}$ \\
\hline
\end{tabular}

Data are presented as mean \pm standard error.

about $2.99 \mathrm{~g} \mathrm{C} / \mathrm{m}^{2} \cdot \mathrm{d}$ (Liu et al., 2020) and carbon sink capacity will increase as salt marsh matures.

In addition, Wilson and Morris (2012) established that the increase in tidal amplitude during spring tide could increase the amount of pore water exchange volume when compared to neap tide. Furthermore, the residence time of water in marshes with high tidal amplitude could be longer, leading to considerable export of DOC (Winter et al., 1996). Assessing pore water exchange rates in salt marsh systems is challenging due to the heterogeneity of salt marsh sediments and the variability of tidal pumping in coastal waters (Tait et al., 2016).

The seasonal export rate trend was consistent with the findings of a previous study conducted in South Carolina (Dame et al., 1986). The Chongming Dongtan salt marsh exhibited the highest export rate in summer among the four seasons, up to $42.8 \%$ for the whole year. Variations in the amount of freshwater input into creeks seemed to be a key factor influencing the direction and magnitude of material fluxes (Ayukai et al., 1998). The possible reasons for the observation could be as follows: First, the diluted water of the Yangtze River transports large amounts of nutrients, which enhances algae productivity, and in turn, indirectly increases the amount of OC generated (Thornton, 2009; Yang et al., 2010). Second, most terrigenous dissolved organic matter (DOM) is deposited or altered within a salinity range of 1 to 24 (Lapin et al., 1990), while a large amount of DOM in the sampling creek is washed away by tides at a salinity of $<1$ in summer and autumn. In addition, estuarine animals are transporters of high quality organic matter and concentrated nutrients. The litter-collecting activity of crabs and the consequent high proportions of litter mineralization in sediments could be key factors influencing the export of OC (Dittmar and Lara, 2001). Most salt marsh sediments are finegrained, and crab holes create preferential flow where dense pore water exchange occurs (Xin et al., 2009; Tait et al., 2017). 
Residues and litters occurring in a marsh considerably influence C transformation in autumn. Duarte et al. (2013) observed that the dieback phenomenon could strongly influence $C$ export with an increase in the amount of litter within the marsh due to increased senescence. In our selected tidal creek system, plant density and biomass gradually decreased in autumn. Low canopy density and the death of rhizomes lead directly to the weakening of soil cohesion (Coleman and Kirwan, 2018), resulting in sediment loss. Therefore, the sediment loss might be the source for POC export through ebb currents in the tidal creek system. Dittmar and Lara (2001) established that annual litterfall accounted for approximately $10 \%$ of the net DOC export.

The export rate in winter and spring was significantly lower than that in summer. The relatively high saline environment in winter and spring promoted the deposition of terrigenous DOM, resulting in a lower export rate than those in summer and autumn. In addition, low temperatures limited microbial activity in the salt marsh, in turn, resulting in varying rates of $\mathrm{C}$ export and availability in the estuary (Schiebel et al., 2018). Photosynthetic fixation of OC increased gradually in spring when compared to winter, with a slightly higher retention capacity in rhizosphere sediments and minimized $\mathrm{C}$ exports in spring throughout the year (Li and Yang, 2015).

The impact of estuarine benthonic fauna on OC should also be considered. A study on Swartkops estuary revealed that macrofaunal and phytoplanktonic communities were the key components of production and turnover for organic and inorganic C. Xin et al. (2009) found that crab burrows could increase the volume of tidally driven water exchange between the sediments and creeks, which may promote organic carbon outwelling. The effect of benthic fauna on horizontal OC output in the Yangtze Estuary remained to be studied.

\section{Uncertainties in Organic Carbon Fluxes}

The present study investigated OC concentrations and fluxes in the east headland marshes of the Yangtze Estuary. The results at tidal creek system level shared were similar to those of estuarine and coastal marshes in the blue $\mathrm{C}$ budget from local to regional scales (Moyer et al., 2015). The findings of the current study could enhance our understanding of OC fluxes in Asian estuaries.

Sampling several individual tides during multiple seasons in such a dynamic environment may not represent the average seasonal variations. $\mathrm{C}$ fluxes in previous studies were obtained using discrete samples collected over one or several tidal cycles with a fixed sampling interval. The deviation can be analyzed using $\mathrm{OC}$ concentration and water flux measurements because OC flux is obtained by multiplying OC concentrations by the water flux.

We failed to capture extremely large flux events for water fluxes. Large amounts of organic matter can be exported from salt marshes during storm surges (Pickral and Odum, 1977; Hackney and Bishop, 1981). Considering the storm intensity, sediment composition, and geomorphology of intertidal marshes, water fluxes in tidal creeks during storms can be several times or even an order of magnitude larger than water fluxes during calm weather (Fan et al., 2019). The estimated annual export could be relatively lower than the actual export if the relationship is applied to the tidal creek system in the present study.

The sampling concentration of OC could have deviated from the actual concentration due to the following reasons.

1. Floating macrodetritus and bedload materials were neglected in the estimation. The sampling concentration was lower than the actual concentration. Pomeroy et al. (1977) also revealed that DOC diffusion rate from marsh sediments was $50 \mathrm{~g} / \mathrm{m}^{2} \cdot \mathrm{yr}$. Thus approximately 21 tons of the annual DOC were underestimated in our tidal creek system according to this diffusion rate.

2. Storms are generally considered to be crucial events that modulate the $\mathrm{C}$ exchange process. Frequent thunderstorms in summer and autumn, especially tropical storms influence material exchange by loosening and dislodging materials. The concentration of $\mathrm{OC}$ during the ebb tide is five to six times the normal concentration despite the rapid increase in water volume in the system (Roman and Daiber, 1989), which could result in lower estimated fluxes than the actual values.

3. Notably, all OC concentrations in the study were based on the spring tide. De la Cruz (1965) established that instantaneous OC concentration during spring tides was two times higher than that of neap tides. Therefore, the values of OC fluxes could be larger than the actual values.

4. This study mainly collected the tidal creek water, which has strong hydrodynamic force and lack of vegetation buffer. The export intensity of OC may be larger than the actual value.

Moreover, due to the misrepresentation of actual hydrological conditions in highly variable bidirectional flow systems, the uncertainty could range from 5 to $1000 \%$ based on sampling frequencies of $15 \mathrm{~min}$ to $12 \mathrm{~h}$ in upscaling mass balances (Etheridge et al., 2015), and the sampling frequency used in the present study was $1 \mathrm{~h}$. Consequently, intensive flux studies are an excellent tool for addressing questions and issues that are specific to a given system, or perhaps to a given coastal region (Childers et al., 2000). Therefore, caution must be taken when scaling or extrapolating and further studies are still required.

In summary, the hydrological output of POC and DOC was of great significance to the dynamic changes in the carbon pool due to the influence of tides. Similarly, the accumulation of exogenous $\mathrm{C}$ caused by flood and ebb tides has facilitated surface evolution, C deposition and long-term C burial (Wetzel, 1992; Yue et al., 2011). Therefore, quantification of lateral $C$ fluxes is essential to accurately assess the $\mathrm{C}$ budget of coastal salt marshes.

\section{CONCLUSION}

(1) DOC and POC concentrations varied among different seasons and different tidal levels. Both concentrations were low when the tide was high due to the dilution effect caused by the large input of river water during high tide.

(2) DOC and POC concentrations were the highest in autumn $(3.54 \pm 0.77$ and $4.19 \pm 0.86$, respectively), and the 
lowest in winter and spring $(1.87 \pm 0.77 \mathrm{mg} / \mathrm{L}$ and $1.51 \pm 0.76 \mathrm{mg} / \mathrm{L}$, respectively).

(3) The organic carbon output showed obvious seasonal variation, ranging from -12.65 to $4.04 \mathrm{~g} \mathrm{C} / \mathrm{m}^{2}$, with the largest in summer, followed by autumn and the smallest in spring. OC fluxes were strongly influenced by tide and water fluxes. During different seasons, the organic carbon flux during the spring tide was significantly higher than that during the neap tide. The rates of $\mathrm{C}$ export observed in the present study are among the highest rates reported for tidal marshes globally, which could be attributed to the strong ebb tides of the Yangtze River Delta.

\section{DATA AVAILABILITY STATEMENT}

The raw data supporting the conclusions of this article will be made available by the authors, without undue reservation.

\section{AUTHOR CONTRIBUTIONS}

YY: conceptualization, formal analysis, and writing-original draft. XL: resources, supervision, and writing-review and

\section{REFERENCES}

Ayukai, T., Miller, D., Wolanksi, E., and Spagnol, S. (1998). Fluxes of nutrients and dissolved and particulate organic matter in 2 mangrove creeks in north-eastern Australia. Mangroves Salt Marshes 2, 223-230. doi: 10.1023/A:1009923410116

Baird, D., Winter, P. E. D., and Wendt, G. (1987). The flux of particulate material through a well-mixed estuary. Cont. Shelf Res. 7, 1399-1403. doi: 10.1016/02784343(87)90044-6

Bauer, J. E., Weijun, C., Raymond, P. A., Bianchi, T. S., Hopkinson, C. S., and Regnier, P. A. G. (2013). The changing carbon cycle of the coastal ocean. Nature 504, 61-70. doi: 10.1038/nature12857

Bittar, T. B., Berger, S. A., Birsa, L. M., Walters, T. L., Thompson, M. E., Spencer, R. G. M., et al. (2016). Seasonal dynamics of dissolved, particulate and microbial components of a tidal saltmarsh-dominated estuary under contrasting levels of freshwater discharge. Estuar. Coast. Shelf Sci. 182, 72-85. doi: 10.1016/j.ecss. 2016.08.046

Bonan, G. B. (2008). Forests and climate change: forcings, feedbacks, and the climate benefits of forests. Science 320, 1444-1449. doi: 10.1126/science. 1155121

Boon, J. D. I. (1975). Tidal discharge asymmetry in a salt marsh drainage system. Limnol. Oceanogr. 20, 71-80. doi: 10.4319/lo.1975.20.1.0071

Borey, R. B., Harcombe, P. A., and Fisher, F. M. (1983). Water and organic carbon fluxes from an irregularly flooded brackish marsh on the upper Texas coast, U.S.A. Estuar. Coast. Shelf Sci. 16, 379-402. doi: 10.1016/0272-7714(83)90101-4

Bouillon, S., Middelburg, J. J., Dehairs, F., Borges, A. V., Abril, G., Flindt, M. R., et al. (2007). Importance of intertidal sediment processes and porewater exchange on the water column biogeochemistry in a pristine mangrove creek (Ras Dege, Tanzania). Biogeosciences 4, 311-322. doi: 10.5194/bg-4-311-2007

Cai, W., Wang, Y., Krest, J., and Moore, W. S. (2003). The geochemistry of dissolved inorganic carbon in a surficial groundwater aquifer in North Inlet, South Carolina, and the carbon fluxes to the coastal ocean. Geochim. Cosmochim. Acta 67, 631-639. doi: 10.1016/S0016-7037(02)01167-5

Cao, L., Song, J. M., Li, X. G., Yuan, H. M., Li, N., and Duan, L. Q. (2013). Research progresses in carbon budget and carbon cycle of the coastal salt marshes in China. Acta Ecol. Sin. 33, 5141-5152. (in Chinese with English abstract). doi: 10.5846/stxb201206030803

Chalmers, A. G., Wiegert, R. G., and Wolf, P. L. (1985). Carbon balance in a salt marsh: interactions of diffusive export, tidal deposition and rainfall-caused editing. LX: visualization. ZX and BY: field investigation. WZ: revise the manuscript. CC: revise and editing. All authors contributed to the article and approved the submitted version.

\section{FUNDING}

This work was supported by the National Natural Science Foundation of China (42141016, 41801253), the National Key Research \& Development Program of China (2017YFC0506000 and PSA 2016YFE0133700), Royal Netherlands Academy of Arts and Sciences (KNAW; PSA-SA-E-02), the 111 Project (BP0820020), and the "Ecology+" Initiative of the East China Normal University.

\section{ACKNOWLEDGMENTS}

We sincerely thank the Shanghai Chongming Dongtan National Nature Reserve for facilitating our experiments. We greatly appreciate the efforts of Kai Tan and Weiwei Qian in data processing and thank Beili Fei for providing experimental data.

erosion. Estuar. Coast. Shelf Sci. 21, 757-771. doi: 10.1016/0272-7714(85) 90071-X

Charette, M. A. (2007). Hydrologic forcing of submarine groundwater discharge: insight from a seasonal study of radium isotopes in a groundwater-dominated salt marsh estuary. Limnol. Oceanogr. 52, 230-239. doi: 10.4319/lo.2007.52.1. 0230

Childers, D. L. (1994). "Fifteen years of marsh flumes: a review of marshwater column interactions in southeastern USA estuaries," in in Global Wetlands: Old World and New, ed. W. J. Mitsch (Amsterdam: Elsevier), 277-293.

Childers, D. L., Day, J. W., and Mckellar, H. N. (2000). “Twenty more years of marsh and estuarine flux studies: revisiting Nixon (1980)," in Concepts and Controversies in Tidal Marsh Ecology, eds M. P. Weinstein and D. A. Kreeger (Dordrecht: Springer Netherlands), 391-423. doi: 10.1007/0-306-47534-0_18

Cifuentes, L. A. (1991). Spatial and temporal variations in terrestrially-derived organic matter from sediments of the Delaware estuary. Estuaries 14, 414-429. doi: $10.2307 / 1352266$

Coleman, D. J., and Kirwan, M. L. (2018). The effect of a small vegetation dieback event on salt marsh sediment transport. Earth Surf. Process. Landforms 44, 944-952. doi: 10.1002/esp.4547

Dame, R. (1991). Annual material processing by a salt marsh-estuarine basin in South Carolina, USA. Mar. Ecol. Prog. 72, 153-166. doi: 10.3354/meps072153

Dame, R., Chrzanowski, T., Bildstein, K., Kjerfve, B., Mckellar, H., Nelson, D., et al. (1986). The outwelling hypothesis and north inlet, South Carolina. Mar. Ecol. Prog. Ser. 33, 217-229. doi: 10.3354/meps033217

De la Cruz, A. A. (1965). A Study of Particulate Organic Detritus in a Georgia Salt Marsh-Estuarine Ecosystem. Ph.D. dissertation. Athens: University of Georgia.

Ding, W. H., Jiang, J. Y., Li, X., Huang, X., Li, X., Zhou, Y. X., et al. (2015). Spatial distribution of species and influencing factors across salt marsh in southern Chongming Dongtan. Chin. J. Plant Ecol. 39, 704-716. (in Chinese with English abstract). doi: 10.17521/cjpe.2015.0067

Dittmar, T. (1999). Nutrient dynamics in a mangrove creek (North Brazil) during the dry season. Mangroves Salt Marshes 3, 185-195. doi: 10.1023/A: 1009903824243

Dittmar, T., and Lara, R. J. (2001). Do mangroves rather than rivers provide nutrients to coastal environments south of the Amazon River? Evidence from long-term flux measurements. Mar. Ecol. Prog. Ser. 213, 67-77. doi: 10.3354/ meps 213067 
Drexler, J. Z., Davis, M. J., Woo, I., and De La Cruz, S. (2020). Carbon sources in the sediments of a restoring vs. historically unaltered salt marsh. Estuaries Coast. 43, 1345-1360. doi: 10.1007/s12237-020-00 748-7

Duarte, C., Middelburg, J., and Caraco, N. F. (2005). Major role of marine vegetation on the oceanic carbon cycle. Biogeosciences 2, 1-8. doi: 10.5194/bg2-1-2005

Duarte, C. M., Losada, I. J., Hendriks, I. E., Mazarrasa, I., and Marbà, N. (2013). The role of coastal plant communities for climate change mitigation and adaptation. Nat. Clim. Chang. 3, 961-968. doi: 10.1038/nclimate1970

Etheridge, J. R., Birgand, F., and Burchell, M. R. (2015). Quantifying nutrient and suspended solids fluxes in a constructed tidal marsh following rainfall: the value of capturing the rapid changes in flow and concentrations. Ecol. Eng. 78, 41-52. doi: 10.1016/j.ecoleng.2014.05.021

Fan, J., Yang, S., Shi, B., Yang, H., Wang, H., Zhang, S., et al. (2019). Impact of storm on water and sediment transportation through tidal creeks of coastal wetlands: a case from Eastern Chongming tidal flat, Yangtze estuary. Mar. Geol. Front. 35 , 11-22. (in Chinese with English abstract).

Fei, B. (2018). Seasonal Characteristics of Dissolved and Particulate Carbon in the Tidal Creeks of the Chongming Dongtan wetland Master. Shanghai: East China Normal University. (in Chinese with English abstract).

Fei, B., Xie, L., Li, S., Chen, W., and Ge, Z. M. (2019). Variations in organic carbon and its impact on tidal creeks within vegetation communities in the coastal wetlands of the Yangtze Estuary. J. East China Normal Univ. Nat. Sci. 1, 156-165. (in Chinese with English abstract).

Fry, B., Justić, D., Riekenberg, P., Swenson, E. M., Turner, R. E., Wang, L., et al. (2015). Carbon dynamics on the louisiana continental shelf and cross-shelf feeding of hypoxia. Estuaries Coast. 38, 703-721. doi: 10.1007/s12237-0149863-9

Ge, Z. M., Cao, H. B., Cui, L. F., Zhao, B., and Zhang, L. Q. (2015). Future vegetation patterns and primary production in the coastal wetlands of East China under sea level rise, sediment reduction, and saltwater intrusion. J. Geophys. Res. Biogeosci. 120, 1923-1940. doi: 10.1002/2015JG003014

Guo, W., Ye, F., Lian, Z., and Jia, G. (2016). Seasonal changes of organic carbon in the Pearl River estuary. J. Trop. Oceanogr. 35, 40-50. (in Chinese with English abstract).

Hackney, C. T., and Bishop, T. D. (1981). A note on the relocation of marsh debris during a storm surge. Estuar. Coast. Shelf Sci. 12, 621-624. doi: 10.1016/S03023524(81)80087-4

Howarth, R. W., Schneider, R., and Swaney, D. (1996). Metabolism and organic carbon fluxes in the tidal freshwater Hudson River. Estuaries 19, 848-865. doi: 10.2307/1352302

Hu, B., Li, G., Bu, R., Li, J., Zhang, Y., and Zhao, J. (2012). Distribution of suspended sediment and particulate organic carbon of the northern Huanghe Delta in winter in China. China Environ. Sci. 32, 1069-1074. (in Chinese with English abstract).

Huang, H., Zhang, L., and Yuan, L. (2007). Temporal and spatial dynamics of salt marsh vegetation in Chongming Dongtan Nature Reserve. Chin. J. Ecol. 27, 4166-4172. (in Chinese with English abstract).

Ivan, V., Teal, J. M., and Volkmann, S. B. (1980). On the measurement of tidal exchanges and groundwater flow in salt marshes. Limnol. Oceanogr. 25, 187-192. doi: 10.4319/lo.1980.25.1.0187

Lapin, I., Anikiyev, V., Vinnikov, Y., Tambiyeva, N., and Shumilin, Y. (1990). Biogeochemical aspects of the behavior of dissolved organic matter in the Razdolnaya river estuary (Amor Gulf, Sea of Japan). Oceanol. Acad. Sci. USSR 30, 170-174.

Li, H., and Yang, S. (2015). Trapping effect of tidal marsh vegetation on suspended sediment, Yangtze Delta. J. Coast. Res. 25, 915-924. doi: 10.2112/08-1010.1

Li, Z., Wang, Y., Cheng, P., Zhang, G., and Li, J. (2016). Flood-ebb asymmetry in current velocity and suspended sediment transport in the Changjiang Estuary. Acta Oceanol. Sin. 35, 37-47. (in Chinese with English abstract). doi: 10.1007/ s13131-016-0923-9

Liu, D., Bai, Y., He, X., Pan, D., Chen, C.-T. A., Li, T., et al. (2019). Satellite-derived particulate organic carbon flux in the Changjiang River through different stages of the Three Gorges Dam. Remote Sens. Environ. 223, 154-165. doi: 10.1016/j. rse.2019.01.012
Liu, J., Yang, S., Shi, B., Luo, X., and Fu, X. (2012). Topography and evolution of the tidal trench in the eastern Chongming tidal flat, Changjiang River Estuary. J. Mar. Sci. 30, 43-50. (in Chinese with English abstract).

Liu, J., Yu, X., Chen, X., Du, J., and Zhang, F. (2020). Utility of radium quartet for evaluating porewater-derived carbon to a saltmarsh nearshore water: implications for blue carbon export-ScienceDirect. Sci. Total Environ. 764:144238. doi: 10.1016/j.scitotenv.2020.144238

Lovelock, C., and Duarte, C. (2019). Dimensions of blue carbon and emerging perspectives. Biol. Lett. 15:20180781. doi: 10.1098/rsbl.2018.0781

Maher, D. T., Santos, I. R., Schulz, K. G., Call, M., Jacobsen, G. E., and Sanders, C. J. (2017). Blue carbon oxidation revealed by radiogenic and stable isotopes in a mangrove system. Geophys. Res. Lett. 44, 4889-4896. doi: 10.1002/ 2017GL073753

McKellar, H. N., and Bratvold, D. (2006). The Role of Tidal Wetlands in Estuarine Nutrient Cycling. New York, NY: Springer.

Mcleod, E., Chmura, G., Bouillon, S., Salm, R., Björk, M., Duarte, C., et al. (2011). A blueprint for blue carbon: toward an improved understanding of the role of vegetated coastal habitats in sequestering $\mathrm{CO}_{2}$. Front. Ecol. Environ. 9:552-560. doi: 10.1890/110004

Middelburg, J. J., Nieuwenhuize, J., Lubberts, R. K., and Plassche, O. V. D. (1997). Organic carbon isotope systematics of coastal marshes. Estuar. Coast. Shelf Sci. 45, 681-687. doi: 10.1006/ecss.1997.0247

Milliman, J. D., and Farnsworth, K. L. (2011). River Discharge to the Coastal Ocean - A Global Synthesis. Cambridge: Cambridge University Press. doi: 10. 1017/CBO9780511781247

Mitchell, C. P. J., Jordan, T. E., Heyes, A., and Gilmour, C. C. (2012). Tidal exchange of total mercury and methylmercury between a salt marsh and a Chesapeake Bay sub-estuary. Biogeochemistry 111, 583-600. doi: 10.1007/s10533-011-9691$\mathrm{y}$

Moore, W. S., Blanton, J. O., and Joye, S. B. (2006). Estimates of flushing times, submarine groundwater discharge, and nutrient fluxes to Okatee Estuary, South Carolina. J. Geophys. Res. Oceans 111:C09006. doi: 10.1029/2005JC0 03041

Moran, M. A., Sheldon, W., and Sheldon, J. (1999). Biodegradation of riverine dissolved organic carbon in five estuaries of the southeastern United States. Estuaries 22, 55-64. doi: 10.2307/1352927

Moyer, R. P., Powell, C. E., Gordon, D. J., Long, J. S., and Bliss, C. M. (2015). Abundance, distribution, and fluxes of dissolved organic carbon (DOC) in four small sub-tropical rivers of the Tampa Bay Estuary (Florida, USA). Appl. Geochem. 63, 550-562. doi: 10.1016/j.apgeochem.2015.05.004

Odum, E. P. (2002). "Tidal marshes as outwelling/pulsing systems," in Concepts and Controversies in Tidal Marsh Ecology, eds M. P. Weinstein and D. A. Kreeger (Dordrecht: Springer Netherlands), 3-7. doi: 10.1007/0-306-47534-0_1

Osburn, C. L., Mikan, M. P., Etheridge, J. R., Burchell, M. R., and Birgand, F. O. (2015). Seasonal variation in the quality of dissolved and particulate organic matter exchanged between a salt marsh and its adjacent estuary. J. Geophys. Res. Biogeosci. 120, 1430-1449. doi: 10.1002/2014JG002897

Pickral, J. C., and Odum, W. E. (1977). "Benthic detritus in a salt marsh tidal creek," in Estuarine Processes, ed. M. Wiley (New York, NY: Academic Press), 280-292. doi: 10.1016/B978-0-12-751802-2.50028-X

Pinsonneault, A. J., Megonigal, P., Neale, P., Tzortziou, M., and Canuel, E. A. (2017). "Trends in brackish marsh dissolved organic carbon in response to surface tidal flooding," in Proceedings of the AGU Fall Meeting, (Washington, DC: American Geophysical Union).

Pomeroy, L. R., Bancroft, K., Breed, J., Christian, R. R., Frankenberg, D., Hall, J. R., et al. (1977). "Flux of organic matter through a salt marsh," in Estuarine Processes, ed. M. Wiley (New York, NY: Academic Press), 270-279. doi: 10.1016/ B978-0-12-751802-2.50027-8

Porubsky, W. P., Weston, N. B., Moore, W. S., Ruppel, C., and Joye, S. B. (2014). Dynamics of submarine groundwater discharge and associated fluxes of dissolved nutrients, carbon, and trace gases to the coastal zone (Okatee River estuary, South Carolina). Geochim. Cosmochim. Acta 131, 81-97. doi: 10.1016/j.gca.2013.12.030

Roman, C. T., and Daiber, F. C. (1989). Organic carbon flux through a Delaware Bay salt marsh: tidal exchange, particle size distribution, and storms. Mar. Ecol. Prog. Ser. 54, 149-156. doi: 10.3354/meps054149 
Romigh, M. M., Davis, S. E., Rivera-Monroy, V. H., and Twilley, R. R. (2006). Flux of organic carbon in a riverine mangrove wetland in the Florida Coastal Everglades. Hydrobiologia 569, 505-516. doi: 10.1007/s10750-006-0152-x

Santos, I. R., Maher, D. T., Larkin, R., Webb, J. R., and Sanders, C. J. (2019). Carbon outwelling and outgassing vs. burial in an estuarine tidal creek surrounded by mangrove and saltmarsh wetlands. Limnol. Oceanogr. 64, 996-1013. doi: 10.1002/lno. 11090

Santos, R., Silva, J., Alexandre, A., Navarro, N., Barrón, C., and Duarte, C. M. (2004). Ecosystem metabolism and carbon fluxes of a tidally-dominated coastal lagoon. Estuaries 27, 977-985. doi: 10.1007/BF02803424

Schiebel, H. N. (2016). Dissolved Organic Carbon Fluxes from a New England Salt Marsh. Doctor of Philosophy. Ph.D. thesis. Boston, MA: University of Massachusetts Boston.

Schiebel, H. N., Gardner, G. B., Wang, X., Peri, F., and Chen, R. F. (2018). Seasonal export of dissolved organic matter from a New England salt marsh. J. Coast. Res. 34, 939-954. doi: 10.2112/JCOASTRES-D-16-00196.1

Sharp, J. H. (1974). Improved analysis for "particulate" organic carbon and nitrogen from seawater. Limnol. Oceanogr. 19, 984-989.

Shisler, J. K., and Jobbins, D. M. (1977). Tidal variations in the movement of organic carbon in New Jersey salt marshes. Mar. Biol. 40, 127-134. doi: 10. $1007 /$ BF00396258

$\mathrm{Su}, \mathrm{J}$. (2001). A review of circulation dynamics of the coastal oceans near China. Acta Oceanol. Sin. 23, 1-16. (in Chinese with English abstract).

Tait, D. R., Maher, D. T., Macklin, P. A., and Santos, I. R. (2016). Mangrove pore water exchange across a latitudinal gradient. Geophys. Res. Lett. 43, 3334-3341. doi: 10.1002/2016GL068289

Tait, D. R., Maher, D. T., Sanders, C. J., and Santos, I. R. (2017). Radium-derived porewater exchange and dissolved $\mathrm{N}$ and $\mathrm{P}$ fluxes in mangroves. Geochim. Cosmochim. Acta 200, 295-309. doi: 10.1016/j.gca.2016.12.024

Thornton, D. C. O. (2009). Spatiotemporal distribution of dissolved acid polysaccharides (dAPS) in a tidal estuary. Limnol. Oceanogr. 54, 1449-1460. doi: 10.4319/lo.2009.54.5.1449

Tipping, E., Marker, A. F. H., Butterwick, C., Collett, G. D., Cranwell, P. A., Ingram, J. K. G., et al. (1997). Organic carbon in the Humber rivers. Sci. Total Environ. 194-195, 345-355. doi: 10.1016/S0048-9697(96)05374-0

Tzortziou, M., Neale, P. J., Megonigal, J. P., Pow, C. L., and Butterworth, M. (2011). Spatial gradients in dissolved carbon due to tidal marsh outwelling into a Chesapeake Bay estuary. Mar. Ecol. Prog. 426, 41-56. doi: 10.3354/meps09017

Van Damme, S., Frank, D., Micky, T., Olivier, B., Eric, S., Britta, G., et al. (2009). Tidal exchange between a freshwater tidal marsh and an impacted estuary: the Scheldt estuary, Belgium. Estuar. Coast. Shelf Sci. 85, 197-207. doi: 10.1016/j. ecss.2009.08.005

Wang, F., Sanders, C. J., Santos, I., Tang, J., and Li, Z. A. (2021a). Global blue carbon accumulation in tidal wetlands increases with climate change. Natl. Sci. Rev. 8:nwaa296. doi: $10.1093 /$ nsr/nwaa296

Wang, F., Tang, J., Ye, S., and Liu, J. (2021b). Blue carbon sink function of chinese coastal wetlands and carbon neutrality strategy. Bull. Chin. Acad. Sci. 3, 241-251. (in Chinese with English abstract).

Webb, J. R., Santos, I. R., Maher, D. T., Tait, D. R., Cyronak, T., SadatNoori, M., et al. (2019). Groundwater as a source of dissolved organic matter to coastal waters: insights from radon and CDOM observations in 12 shallow coastal systems. Limnol. Oceanogr. 64, 182-196. doi: 10.1002/lno.1 1028

Wetzel, R. G. (1992). Gradient-dominated ecosystems: sources and regulatory functions of dissolved organic matter in freshwater ecosystems. Hydrobiologia 229, 181-198. doi: 10.1007/BF00007000

Wilson, A. M., and Morris, J. T. (2012). The influence of tidal forcing on groundwater flow and nutrient exchange in a salt marsh-dominated estuary. Biogeochemistry 108, 27-38. doi: 10.1007/s10533-010-9570-y
Winter, P. E. D., Schlacherl, T. A., and Baird, D. (1996). Carbon flux between an estuary and the ocean: a case for outwelling. Hydrobiologia 337, 123-132. doi: 10.1007/BF00028513

Wolaver, T. G., and Marozas, H. M. (1986). Dissolved and particulate organic carbon in the North Inlet Estuary, South Carolina: what controls their concentrations? Estuaries 9, 31-38. doi: 10.2307/1352190

Woodwell, G. M., Whitney, D. E., Hall, C. A. S., and Houghton, R. A. (1977). The flax pond ecosystem study: exchanges of carbon in water between a salt marsh and long island sound. Limnol. Oceanogr. 22, 833-838. doi: 10.4319/lo.1977.22. 5.0833

Xin, P., Jin, G., Li, L., and Barry, D. A. (2009). Effects of crab burrows on pore water flows in salt marshes. Adv. Water Resour. 32, 439-449. doi: 10.1016/j.advwatres. 2008.12.008

Xing, J. (2014). The Spatial-temporal Distribution and Transportation Characters of Dissolved and Particulate Organic Carbon in the Yangtze River Estuary. Master thesis. Qingdao: Ocean University of China (MsC).

Xing, J., Xian, W., and Sheng, X. (2014). Distribution characteristics of dissolved organic carbon and influence factors in the Yangtze River Estuary during 2012. Period. Ocean Univ. China 44, 74-82. (in Chinese with English abstract).

Yang, G., Zhang, Y., Lu, X., and Ding, H. (2010). Distributions and seasonal variations of dissolved carbohydrates in the Jiaozhou Bay, China. Estuar. Coast. Shelf Sci. 88, 12-20. doi: 10.1016/j.ecss.2010.03.009

Yang, S. L., Li, H., Ysebaert, T., Bouma, T. J., Zhang, W. X., Wang, Y. Y., et al. (2008). Spatial and temporal variations in sediment grain size in tidal wetlands, Yangtze Delta: on the role of physical and biotic controls. Estuar. Coast. Shelf Sci. 77, 657-671. doi: 10.1016/j.ecss.2007.10.024

Yue, B., Zhang, J., and Yi, X. (2011). Carbon biochemical cycle in the wetland ecosystem. Mar. Geol. Front. 27, 72-78.

Yun, C. (2004). Recent Development of the Changjiang Estuary. Beijing: China Ocean Press.

Zhang, L., Gong, P., and Zhang, X. (2005). Review of estuarine organic carbon research. J. Ocean Univ. China 35, 737-744. (in Chinese with English abstract).

Zhao, J., Li, Z., Xu, S., Zhang, E., and Cheng, H. (2019). Vertical profile of suspended sediment concentration in the uppe reach of North Channel in the Changjiang Estuary during the dry season. Resour. Environ. Yangtze Basin 28, 2207-2218. (in Chinsese with English abstract).

Zhu, J., Shen, H., and Zhou, J. (1997). Numerical simulation of the impact of the Subei coastal current on the expansion of the Changjiang River diluted water in summer. J. East Normal Univ. Nat. Sci. 2, 62-67. (in Chinese with English abstract).

Conflict of Interest: The authors declare that the research was conducted in the absence of any commercial or financial relationships that could be construed as a potential conflict of interest.

Publisher's Note: All claims expressed in this article are solely those of the authors and do not necessarily represent those of their affiliated organizations, or those of the publisher, the editors and the reviewers. Any product that may be evaluated in this article, or claim that may be made by its manufacturer, is not guaranteed or endorsed by the publisher.

Copyright (c) 2022 Yuan, Li, Xie, Xue, Yang, Zhao and Craft. This is an openaccess article distributed under the terms of the Creative Commons Attribution License (CC BY). The use, distribution or reproduction in other forums is permitted, provided the original author(s) and the copyright owner(s) are credited and that the original publication in this journal is cited, in accordance with accepted academic practice. No use, distribution or reproduction is permitted which does not comply with these terms. 